\title{
THE IMPLEMENTATION OF THE RIGHT TO EDUCATION IN SOUTH AFRICA AND NIGERIA (PART 1)
}

\author{
Elijah Adewale Taiwo \\ LLB LLM MPhil BL LLD \\ Research Associate, Faculty of Law \\ Nelson Mandela Metropolitan University \\ Port Elizabeth \\ Senior Lecturer, Faculty of Law \\ University of Ibandan, Nigeria \\ Avinash Govindjee \\ BA LLB LLM (Cum Laude) LLD \\ Professor of Law, Faculty of Law \\ Nelson Mandela Metropolitan University \\ Port Elizabeth \\ Attorney of the High Court of South Africa
}

\section{SUMMARY}

This is the first of the two articles dealing with the implementation of the right to education in South Africa and Nigeria. The article examines the meaning and the process of implementation of the right to education as well as the general nature of states' obligations under the international human rights instruments regarding the right to education. The article examines the measures put in place at the international level towards realizing the right to education. While this first article examines legislative measures, the follow-up article examines the non-legislative measures, that is, administrative measures as well as other measures put in place to ensure the implementation of the right to education. The right to education is an empowerment right which is given wide recognition in a number of important international and regional human rights instruments as well as in national constitutions. The article argues that in terms of the international human rights instruments, states are obliged to make primary, secondary and higher levels of education available, accessible, acceptable and adaptable to all in their territories. It posits that by having ratified those international agreements in which the right to education is guaranteed, both South Africa and Nigeria assumed obligations under international law enjoining them to realize the right to education and to respect freedoms in education in their respective territories. It submits that, despite the international obligations and commitments to provide education for all, there is a significant gap between what is stipulated and the practical realities in the two countries. 


\section{$1 \quad$ INTRODUCTION}

The right to education is a right which is given wide recognition in a number of important international and regional human rights instruments. ${ }^{1}$ The Universal Declaration of Human Rights (UDHR), 1948, which is the watershed of all human rights instruments, provides for the right of everyone to education in the following terms: "[e]veryone has the right to education. Education shall be free, at least in the elementary and fundamental stages. Elementary education shall be compulsory. Technical and professional education shall be made generally available and higher education shall be equally accessible to all on the basis of merit." In the same manner, the International Covenant on Economic, Social and Cultural Rights (ICESCR), 1966 provides for the right of everyone to education. ${ }^{3}$ The ICESCR states, inter alia, that primary education shall be compulsory and available freely to all; secondary education shall be made generally available, while higher education shall be made equally accessible to all, on the basis of capacity. ${ }^{4}$ Apart from the UDHR and the ICESCR, there are several other international and regional human rights instruments in which the right to education has been formally recognized. ${ }^{5}$ In the same vein, human rights instruments protecting vulnerable groups such as the Convention on the Rights of the Child (CRC), 1989 and the the Convention on the Elimination of Discrimination Against Women (CEDAW), 1979 have equally provided for the right to education. Apart from the ICESCR, the CRC also makes elaborate, clear and specific provision for the protection of the right of a child to education. The CRC contains a comprehensive set of legally enforceable commitments concerning the rights to education. ${ }^{6}$ The Convention reaffirms the right of every child to free and compulsory primary schooling, and states further that higher levels of education should be accessible to all without

See Tomasevski "Has the Right to Education a Future within the United Nations? A Behindthe-Scenes Account by the Special Rapporteur on the Right to Education 1998-2004" 2005 5(2) Human Rights LR 205 224; see also, Dlamini "Culture, Education, and Religion" in Van Wyk, Dugard, De Villiers and Davis Rights and Constitutionalism: The New South African Legal Order (1994) 573 581; and Ssenyonjo Economic, Social and Cultural Rights in International Law (2009) 359.

Art 26(1) of the UDHR, 1948.

See arts 13 and 14 of the ICESCR.

See art 13(2)(a), (b) and (c) of the ICESCR.

5 See art 19(2), ICCPR which, though not expressly providing for the right to education, states that the provision of the article is wide to encompass the right to education. See also, art 10 of the Convention on the Elimination of Discrimination Against Women (CEDAW) 1979; arts 23, 24 and 29 of the Convention on the Rights of the Child (CRC) 1989; art 17 of the African Charter on Human and Peoples' Rights (ACHPR) 1981; African Charter on the Rights and Welfare of the Child 1990; art 4 of the UNESCO Convention Against Discrimination in Education 1960; the World Declaration on Education for All-Meeting Basic Learning Needs, adopted by the World Conference on Education for All on 9 March 1990; European Convention, 1953; American Declaration of the Rights and Duties of Man 1948; and art 5 of the ICERD, 1965 among others. Apart from the human rights law, other laws such as refugee law and humanitarian law, migration law and trade law equally regulate education.

6 See arts 28, 29, 30 \& 31 of the CRC. 
discrimination of any kind. ${ }^{7}$ It also protects the child from exploitative work that might interfere with his/her education. ${ }^{8}$

At the African regional level, the African Charter on Human and Peoples' Rights (ACHPR), 1981 recognizes the right of everyone to education by stating that "[e]very individual shall have a right to education." Similarly, at the national level, the right to education has also received recognition in most national constitutions. ${ }^{10}$ While some states protect this right in their constitutions in the form of a fundamental right, enforceable at law, others do so in a form of a directive principle of state policy. ${ }^{11}$ In this first category is the Constitution of the Republic of South Africa, 1996 which expressly provides for the right to education together with other social, economic and cultural rights, as fundamental rights in its Bill of Rights. ${ }^{12}$ The Constitution of the Federal Republic of Nigeria (CFRN), 1999 (as amended) falls within the second category. The Nigerian Constitution (in its second chapter) categorizes social, economic and cultural rights, including the right to education, under the heading "fundamental objectives and directive principles of the state policy" which, according to section 6(6)(c) of the Constitution, are non-justiciable. ${ }^{13}$

Both South Africa and Nigeria have ratified this Convention.

See art 32 of CRC.

Art $17(1)$ of the ACHPR.

10 Heyns and Kaguongo observed that the right to education has received recognition in 45 African Constitutions. See Heyns and Kaguongo "Constitutional Human Rights law in Africa" $200622(4)$ SAJHR 673699.

11 See Ssenyonjo Economic, Social and Cultural Rights 152-153; and Miamingi "Inclusion by Exclusion? An Assessment of the Justiciability of Socio-Economic Rights under the 2005 Interim National Constitution of Sudan" 2009 9(1) African Human Rights LJ 76 77. There are also some other states whose constitutions do not afford explicit recognition to the right to education, but even in these instances, education is seen as virtually an important public function. In this group is the United States of America. Thus, in Plyler v Doe 457 U.S. 202 (1982), the Supreme Court of the United States of America expressed as follows: "Public education is not a 'right' granted to individuals by the Constitution. But neither is it merely some governmental 'benefit' indistinguishable from other forms of social welfare legislation ... American people have always regarded education and [t]he acquisition of knowledge as matters of supreme importance. We have recognized the public schools as a most vital civic institution for the preservation of a democratic system of government, and as the primary vehicle for transmitting the values on which our society rests ..." See also, Brown v Board of Education 347 U.S. 483 (1954).

12 See Chap 2 of the Constitution. For including a range of justiciable social, economic and cultural rights together with civil and political rights in its provisions, the 1996 South African Constitution has been described as "the most admirable constitution in the history of the world". See Sunstein Designing Democracy: What Constitutions Do (2001) 261.

13 See Archbishop Anthony Olubunmi Okogie v Attorney General of Lagos State (1981) 1 NCLR 218; Uzuokwu v Ezeonu II [1991] 6 NWLR (pt 200) 708; Olowu "Human Rights and the Avoidance of Domestic Implementation: The Phenomenon of Non-Justiciable Constitutional Guarantees" 2006 69(1) Saskatchewan LR 39-78 56-60; and Olowu "The Right to Social Security in Nigeria: Taking Up the Gauntlet" 2007 1(2) CALS Review of Nigerian Law and Practice 91-107 101. However, the recent decision of the ECOWAS Court in Registered Trustees of the Socio-Economic Rights \& Accountability Project (SERAP) v Federal Republic of Nigeria \& Universal Basic Education Commission (Suit No: ECW/CCJ/App/0808 delivered on 27/10/2009) is to the effect that Nigerians have the right to education. It is submitted that the court did not decide this in terms of the 1999 Nigerian Constitution but rather in terms of Art 17 of the African Charter on Human and Peoples' Rights. It held: "[t]he directive principles of state policy of the Federal Republic of Nigeria are 
The South African Constitution clearly provides that everyone has the right to a basic education, including adult basic education; ${ }^{14}$ and to further education which the state, through reasonable measures, must make progressively available and accessible. ${ }^{15}$ It provides further that everyone has the right to receive education in the official language or languages of his/her choice in a public educational institution, ${ }^{16}$ as well as the right to establish and maintain independent educational institutions. ${ }^{17}$ In Nigeria, on the other hand, the "right" to education is guided by section 18 of the Constitution which provides that government shall direct its policy towards ensuring that there are equal and adequate educational opportunities at all levels. ${ }^{18}$ The section states further that the Nigerian government shall strive to eradicate illiteracy and shall, when practicable, provide free education at all levels. ${ }^{19}$

\section{RATIONALE FOR THE COMPARISON}

This article attempts to compare the implementation of the right to education in South Africa and Nigeria. According to Hayden, to "compare" is to examine two or more entities by putting them side by side and looking for similarities and differences between or among them. ${ }^{20}$ It is an established fact that the primary purpose of any exercise in legal comparison is the creation of new knowledge. ${ }^{21}$ In this regard, Kung defines the comparative legal method of research as "a unique, systematic and jurisprudential strategy applied, by virtue of similarities and differences between the diverse legal systems, to acquire new understanding regarding the specific topic

not justiciable before this Court as argued by second defendant and the fact was not contested by the plaintiff. And granted that the provisions under the directive principles of state policy were justiciable, it would be the exclusive jurisdiction of the Federal High Court, being a matter solely within the domestic jurisdiction of the Federal Republic of Nigeria ..." SERAP v Federal Republic of Nigeria supra par 17.

1 S 29(1)(a) of the South African Constitution 1996.

5 S 29(1)(b) of the South African Constitution 1996.

S 29(2) of the South African Constitution 1996.

S 29(3) of the South African Constitution 1996.

S 18(1) of the CFRN 1999.

19 See S 18(3)(a)-(d) of the CFRN 1999. Emphasis added. However, in support of this constitutional mandate, the Nigerian Child Rights Act, 2003 in addition to providing for comprehensive provisions on the protection of the rights of the child, also guarantees the right of Nigerian child to education. The Act in its s 15(1) states that "[e]very child has the right to free, compulsory and universal basic education and it shall be the duty of the Government in Nigeria to provide such education". See also, s 2(1) of the Compulsory, Free, Universal Basic Education Act, 2004.

20 Hayden Introduction to International Education (2006) 4; and according to Watson, "comparative law then, as an academic discipline in its own right, is a study of the relationship, above all the historical relationship, between legal systems or between rules of more than one system". See Watson Legal Transplants (1973) 9.

21 According to Venter, comparative law also an aid to legislative process; an instrument of interpretation of the law; a vehicle for teaching law, and a means of promoting legal unification. See Venter Constitutional Comparison (2000) 19. 
...22 Various scholars have justified a comparative study as serving many
useful purposes.

Engaging in a kind of comparison such as this has its own practical value in this age of globalization. Apart from acquiring knowledge on a particular subject, the concept of universal education within the concept of the Millennium Development Goals (MDGs) justifies this comparison. ${ }^{24}$ As Roach observed, "a globalised world is one where people, including judges, engage in multiple and ongoing conversations that cross borders. It is a world characterised by a sense of openness, modesty, and willingness to learn from others. ${ }^{25}$ It is observed that courts around the world are frequently confronted by many of the same difficult issues and the judicial world is becoming a global village where judges in different jurisdictions are increasingly looking to a wide variety of sources to interpret their own human rights' provisions. $^{26}$

In today's complex society, law-makers as well as legal scholars, are often faced with difficult problems to which knowledge of laws and rules from other jurisdictions may offer appropriate solutions. In this regard, the Constitution of the republic of South Africa, 1996, obliges a court or tribunal to promote the values that underlie an open and democratic society based on human dignity, equality and freedom. ${ }^{27}$ It sets out the general approach to be followed when interpreting the Bill of Rights. ${ }^{28}$ In the South African context,

22 Kung An International Perspective on the Fundamental Human Rights of Educators (2006) 7. It is acknowledged that comparative law is a method of study; in fact, De Cruz asserts categorically that comparative law is neither a branch of law, nor a legal body of rules but rather, a method of study. See generally, De Cruz Comparative Law in a Changing World (1995) 3-5; and Venter Constitutional Comparison 16-17.

23 Sacco says that a comparative evaluation of different countries concerning the same or similar issues is also of great value for drafting of legislation or recommending a law reform. See Sacco "Legal Formant: A Dynamic Approach to Comparative Law" 1991 African Journal of Comparative Law 14 ; and Hervey justifies a comparative study by saying that it is a potent instrument for a better understanding of one's domestic legal system. See Hervey Justifications for Sex Discrimination in Employment (1993) 17; and Bogdan equally asserts that realization has come in the recent time that a lawyer like any other professional cannot limit his attention only to what occurs within the borders of his own country. He argues as follows: "The importance of learning from the experience of other countries is obvious within the fields of natural science, medicine, and technology. The same compelling need to make use of the experience of others should also be recognized within the legal field." See Bogdan Comparative Law (1994) 20 and 29.

24 Hutchison and Wiggan "Introduction: The Intersections of Globalisation, Education, and the Minority Experience" in Wiggan and Hutchison (eds) Global Issues in Education: Pedagogy, Policy, Practice and the Minority Experience (2009) 1-19 17.

25 Roach "Constitutional, Remedial, and International Dialogues about Rights: The Canadian Experience" 2004-2005 40 Texas International LJ 537-576 538.

26 Govindjee "Lessons for South Africa Social Assistance Law From India: Part 1 - The Ties that Bind: The Indina Constitution and Reasons for Comparing South Africa with India" 2005 26(3) Obiter 575; L'Heureux-Dube "Human Rights: A Worldwide Dialogue" in Kirpal, Desai, Subramanium, Dhavan and Ramachandran (eds) Supreme But Not Infallible: Essays in Honour of the Supreme Court of India (2000) 214 215; and see also, Taiwo "Repugnancy Clause and its Impact on Customary Law: Comparing the South African and Nigerian Positions - Some Lessons for Nigeria" 2009 34(1) Journal For Juridical Science 89-115 9394.

27 See s 39(1)(a)-(c) of the Constitution.

28 Ibid. 
the comparative method is legitimate and is sanctioned by the Constitution. ${ }^{29}$ In terms of the provision of section 39 the South African Constitution, a court or a tribunal must consider international law and may consider foreign law. ${ }^{30}$ The provision endorses a valued-based approach to the interpretation of the Bill of Rights and indicates the openness of the Constitution to international and comparative law sources in the interpretation of the Bill of Rights. ${ }^{31}$

The provision obliging the court to interpret any legislation or Bill of Rights consistently with international law has put the South Africa judiciary in a good position in terms of supporting a comparative-friendly approach. Although, unlike the South African Constitution, the Nigerian Constitution does not expressly oblige a court or a tribunal to consider international and foreign laws, however, Nigerian courts have also recognized the importance of a comparative venture. Thus, in Augustina Chinyelu Ugo v Dr. Roy Pedro $U_{g o,}{ }^{32}$ the Nigerian Court of Appeal observed thus: "[t]his world has become a global village where the rule of law and justice as they affect human relations are universal. ${ }^{33}$

Though South Africa and Nigeria are different in terms of political climate, social values and traditions, the economies of the two countries as well as demographic factors are also different. The underlying legal system of South Africa is a Roman-Dutch-English hybrid of civil code and common law, ${ }^{34}$ while the Nigerian underlying legal system is based on English common law. Also, the South African Constitution is structured differently from the Nigerian Constitution; nevertheless, these two countries are comparable

29 Brand Financial Constitutional Law: A Comparison Between Germany and South Africa (2006) 6.

30 For instance, in $S$ v Makwanyane 1995 (6) BCLR 665 (CC); and $S$ v Williams 1995 (7) BCLR 861 (CC), the South African Constitutional Court did extensive research (on the universally recognized fundamental right to life and the right to be free from cruel and inhuman punishment respectively) to shed light on the interpretation of these rights in the South African context. In both cases, the Court looked for guidelines in foreign law and cases and specifically, in $S v$ Williams, a Namibian and a Zimbabwean case on corporal punishment were consulted. The Constitutional Court also used the comparative method in several instances during the certification process. See eg, Certification of the Constitution of the Republic of South Africa, 19961996 (4) SA 744 (CC) par 50, 71-73, 89-90 and 112-113. Similarly, in Bhe v Magistrate Khayelitsha; Shibi v Sithole; SA Human Rights Commission v President of the Republic of South Africa 20051 BCLR 1, the South African Constitutional Court relied heavily on the Nigerian case of Augustine N Mojekwu v Caroline MO Mojekwu [1997] 7 NWLR (pt 512) 283 on the issues of primogeniture and gender discrimination. See also, Sidumo v Rustenburg Platinum Mines Ltd 2008 (2) SA 24 (CC), 2008 (2) BCLR 158 (CC), Sachs J, par [149].

31 See Liebenberg "Reflection on Drafting a Bill of Rights: A South African Perspective" in Kersting (ed) Constitution in Transition: Academic Inputs for a New Constitution in Zimbabwe (2009) 15; and see also, Joubert and Prinsloo The Law of Education in South Africa 2ed (2009) 36.

32 [2008] 5 NWLR (pt 1079) 1.

33 Adekeye JCA (as she then was) at 24. In the same vein, Adediran also submits thus: "[t]oday, the world is a global village, which means that the study and research in law can no longer be restricted within one's country. The tendency therefore is how to explore avenues where the law is generally made available to aid any resident of the country, coming from any part of the globe". See Adediran Essays on Tribunals and Inquiries in Nigeria (2004) 117.

34 Kende Constitutional Rights in Two Worlds South Africa and the United States (2009) 5. 
because of their common historical link. They both have strong connections to the British legal tradition, and the common law, being former British colonies. Economically and politically, South Africa and Nigeria constitute regional superpowers accounting for more than half of Sub-Saharan Africa's domestic product. ${ }^{35}$ The two countries also share common human rightsrelated problems. While South Africa emerged from a long period of apartheid system, Nigeria, on the other hand, transited from autocratic dictatorship of a long military rule.

In the context of this article, the reason for comparing Nigeria and South Africa is based principally upon the stark difference in the constitutional treatment given to the right to education in the two jurisdictions. South Africa deliberately incorporated a wide range of economic, social and cultural rights in its Bill of Rights and claims of violations of these rights have been successfully tested before courts. The Nigerian Constitution, by contrast, protects some economic, social and cultural rights as "directive principles of State policy". Given the divergent treatment of the right to education in the countries, as well as the obvious contextual and actual differences between the two legal systems on the whole, it is a special challenge to suggest that lessons are to be drawn for either or both countries. This article endeavours to attempt this challenge by specifically contemplating the manner in which the South African position regarding the right to education is able to inform Nigeria's interpretation of the right to education, despite Nigeria not providing for the right to education as a justiciable constitutional right.

\section{MEANING AND THE PROCESS OF IMPLEMENTATION}

The right to education, like all other human rights, brings with it a set of globally agreed norms or standards. This gives rise to state obligations in relation to which effective and transparent monitoring and accountability mechanisms are required. ${ }^{36}$ The importance of the right to education cannot be overemphasized, given that it is a right which is given express recognition in a number of important human rights instruments. The term "implementation" itself needs to be properly contextualized, although it is accepted that it is a loose concept defying absolute definition. ${ }^{37}$

According to Mazmanian and Sabatier, implementation may refer to "those events and activities that occur after the issuing of authoritative public

35 Hutchison and Wiggan "Introduction: The Intersections of Globalisation, Education, and the Minority Experience" in Global Issues in Education: Pedagogy, Policy, Practice and the Minority Experience 17; and see also LaFraniere "World Bank Reports Progress in SubSaharan Africa" 15 November 2007 New York Times A3.

36 Ssenyonjo Economic, Social and Cultural Rights 399.

37 Victor, Raustiala and Skolnikoff state: "implementation is a complex process that ... is illsuited to the construction of parsimonious theories. Yet implementation is what turns grand principles and commitments into actual practice ..." See Victor, Raustiala and Skolnikoff "Introduction and Overview" in Victor, Raustiala and Skolnikoff (eds) The Implementation and Effectiveness of International Environmental Commitments: Theory and Practice (1998) 1,4 and 29. 
policy directives, which include the effort to administer and the substantive impacts on people and events. ${ }^{38}$ In this context, implementation connotes the process of converting normative content of the right to education into practical realities; it denotes a process of putting the human-rights instruments and standards into effect. ${ }^{39}$ Implementation is regarded as the central process that turns commitments into action. ${ }^{40}$ In this article, the term "implementation" is used to denote the process of translating international human-rights commitments into action, as well as the process of implementing those commitments at the national level. It includes the myriad of governments' acts, such as promulgation of laws and regulations and formulation of policies towards achieving these commitments. ${ }^{41}$ It also extends to cover the activities of international institutions monitoring and assisting national governments as they put international commitments into practice. $^{42}$

As pointed out above, the right to education is given wide recognition in several international, regional and national human-rights instruments. ${ }^{43}$ Despite the universal recognition of the right to education as a fundamental right, the realization of this right remains especially elusive in the developing countries. ${ }^{44}$ The enjoyment of the right to education, especially for girls and women, remains a distant goal for millions of individuals throughout the world, especially in sub-Saharan Africa. ${ }^{45}$ It is observed that discrimination

38 See Mazmanian and Sabatier Implementation and Public Policy (1983) as quoted by Victor et al "Introduction and Overview" in The Implementation and Effectiveness of International Environmental Commitments 4.

39 This is what Halliday and Schmidt referred to as bringing "law on the book" into "law-inaction". See Galligan and Sandler "Implementing Human Rights" in Halliday and Schmidt (eds) Human Rights Brought Home: Socio-Legal Perspectives on Human Rights in National Context (2004) 7, 26 and 29.

40 Victor et al "Introduction and Overview" in The Implementation and Effectiveness of International Environmental Commitments 15.

41 Victor et al "Introduction and Overview" in The Implementation and Effectiveness of International Environmental Commitments 4.

42 Ibid.

43 See art 26, UDHR; arts 13 and 14, ICESCR, art 19(2), ICCPR, arts 28, 29, 30, 31 and art 32 of the Convention on the Rights of the Child (CRC), art 10 of the Convention on the Elimination of Discrimination Against Women (CEDAW) 1979; arts 23, 24 and 29 of the Convention on the Rights of the Child (CRC) 1989; art 17 of the African Charter on Human and Peoples' Rights (ACHPR) 1981; African Charter on the Rights and Welfare of the Child 1990; the UNESCO Convention Against Discrimination in Education 1960; the World Declaration on Education for All-Meeting Basic Learning Needs, adopted by the World Conference on Education for All on 9 March 1990; European Convention 1953; American Declaration of the Rights and Duties of Man 1948 among others. See also, s 29 CRSA, 1996 \& s 18, CFRN, 1999.

44 As UNESCO recently observed, "at the dawn of the century 875 million of the world's citizens are illiterate. One out of every five children aged 6-11 in developing countries - an estimated 113 million - is not in school, 60 percent of them are girls. Nine countries Bangladesh, Brazil, China, Egypt, India, Indonesia, Mexico, Nigeria and Pakistan (E9) - are home to 70 percent of the world's illiterates. Girls and women are most at risk. See UNESCO Education for All: An Achievable Vision (2000) 3.

45 Asserting this, Coomans states: "[i]t is a commonplace to say that everyone has a right to education. However, it is a matter of common knowledge that there is a big gap between the right to education laid down by international texts and the persistence of some disenchanting realities." See Coomans "Content and Scope of the Right to Education as a 
against girls and women in societies impedes access to education and constitutes a major obstacle on the path towards achieving equal education for all. ${ }^{46}$ In this regard, Dall asserts that millions of school-age children have no access to any kind of basic education service across the globe. ${ }^{47}$ Also, several million adults are illiterates out of which almost two-thirds are women. ${ }^{48}$ Despite the MDGs aiming at ensuring that children everywhere in the world are able to complete a full course of good-quality education at all levels by 2015 , sub-Saharan Africa still has a large number of out-of-school children and illiterate adults. In terms of quality, it is observed that the quality of education is poor with millions entering schools but not learning enough to meet their basic learning needs. ${ }^{49}$

In South African and Nigerian schools in particular, it is noted that the link between access and success is weak. ${ }^{50}$ This issue assumes greater significance as a result of the declining standard of the respective schoolcertificate examinations. ${ }^{51}$ It is accepted that school-certificate examination

Human Right and Obstacles to Its Realisation" in Donders and Volodin (eds) Human Rights in Education, Science and Culture (Legal Developments and Challenges) (2007) 183.

Ssenyonjo Economic, Social and Cultural Rights 358.

4 Dall "Children's Right to Education: Reaching the Unreached" in Himes (ed) Implementing the Convention on the Rights of the Child (1995) 143; and see also Coomans "Content and Scope of the Right to Education as a Human Right and Obstacles to Its realisation" in Human Rights in Education, Science and Culture 183.

48 See Coomans "Content and Scope of the Right to Education as a Human Right and Obstacles to Its realisation" in Human Rights in Education, Science and Culture 183.

49 Capturing this problem globally, Paul submits thus: "[m]ost educational commentators and most of the general public seem to agree on at least one thing: the schools are in deep trouble. Many graduates, at all levels, are characterized as lacking the abilities to read, write and think with a minimum level of clarity, coherence and a critical/analytical exactitude ..." See Paul "McPeck's Mistakes" in Scheffler, Howard and McPeck (eds) Teaching Critical Thinking (1990) 102; see also Dall "Children's Right to Education: Reaching the Unreached" in Implementing the Convention on the Rights of the Child 143; and Coomans "Content and Scope of the Right to Education as a Human Right and Obstacles to Its Realisation" in Human Rights in Education, Science and Culture 183.

50 See Berger "The Right to Education under the South African Constitution" 2003103 Columbia LR 614, 619-620 and 661; Jansen "Reflections on Meaningful Access to Education" in Pendlebury, Lake and Smith (eds) South African Child Gauge 2008/2009 (2009) 7-8; DFID Document on Education in Nigeria http://www.dfid.gov.uk/document/ publications/PSA/E Nigeria.pdf (accessed on 2009-08-08); and UNESCO Education for All Global Monitoring Report 2009 http://www.unesco.org/education/gmr2009/press/GMR2009 RO SSA.pdf (accessed on 2009-08-08).

51 For instance, the results of the National Senior Certificate Grade 12 examinations for 2009 , released in January 2010 reflect a drop in students' performance in South African schools. The national pass rate of the National Senior Certificate examinations for 2009 was $60.7 \%$. This shows a consistent decline of $2 \%$ per year from the 2008 and 2007 pass rates. See Statement by the Minister of Basic Education, Mrs Angie Motshekga, MP, on the announcement of the National Senior Certificate Grade 12 Examination results for 2009 on 7 January 2010 at Pretoria http://www.news24.com/Content/SouthAfrica/News/1059/dfaaa 691ee6e44529f716638cd4ba931/07-01-2010-08-27/Matric results Ministers full speech (accessed on 2010-07-01). In the same vein, in Nigeria, the poor results in the Senior School Certificate Examinations (SSCE) conducted by the West African Examinations Council (WAEC) and the National Examinations Council (NECO) in May/June 2009 are clear indications of a progressive slide in the Nigerian educational system. This poor pattern was repeated in the 2010 May/June Examinations recently released by WAEC with only 24.94 percent of the candidates passing in English and Mathematics. See Uwadiae "WASSCE Result: Only 24.94\% obtain Credits in English, Maths" 20 August 2010 The 
results are a major visible indicator of the strengths and weaknesses in the national educational system. The poor secondary-schools results in the two countries should, therefore, provide some opportunity for analysing the factors which are accountable for the high failure rate, as well as the possibilities for improving the educational system in both countries. The ICESCR stipulates the obligation of a state party to ensure full realization of the rights recognized under the covenant, including the right to education. It is observed, however, that measuring the progress in realizing economic, social and cultural rights poses problems. ${ }^{52}$ This is so because the process not only requires an assessment of current programmes and performance, but also a determination as to whether a state is moving expeditiously towards the goal of full implementation, using the full extent of available resources. ${ }^{53}$

The pertinent issue, therefore, is how to determine the actual nature of the states parties' implementation of their obligations under the ICESCR. What are the indicators to determine when a violation of economic, social and cultural rights has occurred? The Limburg Principles provide some guidance in this regard, by stating that "a failure by a State Party to comply with an obligation contained in the International Covenant on Economic, Social and Cultural Rights is, under international law, a violation of the International Covenant on Economic, Social and Cultural Rights. ${ }^{54}$ The next section of this article provides an overview of the nature of the states' obligations and the implementation strategies put in place under the ICESCR and other allied human-rights instruments. This approach, it is submitted, provides a solid foundation to identify the content of the right to education and the corresponding states' obligations in South Africa and Nigeria.

\section{THE NATURE OF THE STATES' OBLIGATIONS}

Article 2(1) of the ICESCR provides: "[e]ach States Party to the present Covenant undertakes to take steps, individually and through international assistance and co-operation, especially economic and technical, to the maximum of its available resources, with a view to achieving progressively the full realization of the rights recognized in the present Covenant by all appropriate means, including particularly the adoption of legislative measures". Similarly, article 4 of the Convention on the Rights of the Child

Punch Newspaper 37; see also "Mass Failure in WAEC and NECO Exams" 19 October 2009 The Guardian http://www.nigeriamasterweb.com/paperfrmes.html (accessed on 200910-19-); and "WASSCE: Huge Resources, Poor Performance" 19 March 2010 The Punch Newspaper 36.

52 Rishmawi The Nature of States Parties Obligations (A Commentary on the United Nations Convention on the Right of the Child) (2006) 33 par 87.

53 Ibid.

54 See "The Limburg Principles on Implementation of the International Covenant on Economic, Social and Cultural Rights" 19879 Human Rights Quarterly 122 par 70. Relating this to the right to education, Beiter submits that the failure of a state to comply with the right to education as laid down in international agreements amounts to a violation of international law, entailing the international responsibility of the states. See Beiter The Protection of the Right to Education by International Law (2006) 2 and 3. 
(CRC) says: "States Parties shall undertake all appropriate legislative, administrative, and other measures for the implementation of the rights recognized in the present Convention. With regard to economic, social and cultural rights, States Parties shall undertake such measures to the maximum extent of their available resources and, where needed, within the framework of international co-operation. ${ }^{.55}$ It should be noted that these provisions use the formulation "in all appropriate means, including particularly the adoption of legislative measures" in qualifying the states' obligations.

The nature and scope of the states parties' obligations under the ICESCR, and the nature and scope of violations of the economic, social and cultural rights and appropriate responses and remedies have been examined by groups of experts in international law who adopted the Limburg Principles on the Implementation of the ICESCR in $1986^{56}$ and Maastricht Guidelines on Violations of Economic, Social and Cultural Rights in $1997 .^{57}$ Although the Limburg Principles and Maastricht Guidelines are not legally binding per se, they provide a subsidiary means for the interpretation of the Covenant as "teachings of the most highly qualified publicists of the various nations." ${ }^{58}$ The participants who adopted the Maastricht Guidelines considered them to reflect the evolution of international law since 1986. ${ }^{59}$ The Committee on Economic, Social and Cultural Rights (CESCR) has also (in its numerous General Comments) spelt out the content of the obligations and rights under the Covenant, to which no state has ever raised any formal objections.

While these General Comments are not binding, they carry substantial weight in the interpretation of the rights they address. ${ }^{60}$ In the context of a human-rights treaty that was specifically drafted in such a way as to accommodate disparities among state parties, the interpretations given to its contents by the CESCR are indeed invaluable. ${ }^{61} \mathrm{~A}$ striking feature of the General Comments is the consistent effort of the CESCR to identify aspects

55 See a similar provision in art 2(2) of the ICCPR which states: "[w]here not already provided for by existing legislative, or other measures, each State Party to the present Covenant undertakes to take the necessary steps, in accordance with its constitutional processes and with the provisions of the present Covenant, to adopt such laws or other measures as may be necessary to give effect to the rights recognised in the present Covenant." Art 1 of the African Charter on Human and Peoples' Rights, 1981 also contains similar provision. It states: "[t]he Member States of the Organization of African Unity, Parties to the present Charter shall recognise the rights, duties and freedoms enshrined in this Charter and shall undertake to adopt legislative or other measures to give effect to them". See also art 1(1) of the African Charter on the Rights and Welfare of the Child (ACRWC) adopted by the OAU in 1990 (OAU Doc. CAB/LEG/24.9/49).

56 The Limburg Principles on the Implementation of the International Covenant on Economic Social and Cultural Rights of 6 June 1986 (UN Doc. E/CN.4/1987/17, 1987) and (1987) 7 Human Rights Quarterly 122-135. The Limburg Principles were adopted by a group of 29 participants.

57 See Maastricht Guidelines on Violations of Economic, Social and Cultural Rights (UN Doc. E/C.12/2000/13/2000); see also, (1998) 20(3) Human Rights Quarterly 691-704. The Maastricht Guidelines were adopted by a group of more than 30 experts.

58 Ssenyonjo Economic, Social and Cultural Rights 52.

59 Ibid.

60 Olowu An Integrative Right-Based Approach to Human Development in Africa (2009) 39.

61 Ibid. 
of each right that are capable of immediate implementation. ${ }^{62}$ Over the course of time, the CESCR General Comments have become highly instructive and materially instrumental in the interpretation of conventional human-rights law at regional and national levels. ${ }^{63}$

On the importance of the General Comments, in Social and Economic Rights Action Centre (SERAC) $v$ Nigeria ${ }^{64}$ for instance, the African Commission on Human and Peoples' Rights (African Commission) relied extensively on General Comments Numbers 3, 4, 7, and 14 to hold that the Federal Government of Nigeria had violated the rights to housing, food and health. Prior to this decision, in interpreting the "reasonableness" of the housing policy of the South African government, the Constitutional Court of South Africa applied General Comments Numbers 3 and 4 in Government of the Republic of South Africa $v$ Grootboom ${ }^{65}$ to define the nature and scope of the constitutional provisions on the subject. ${ }^{66}$

In terms of the provisions of article 2(1) of the ICESCR and article 4 of the $\mathrm{CRC}$, the nature of states parties' obligations consists of three important elements. First, states parties are to take "all appropriate legislative, administrative, and other measures for the implementation of the rights recognized in those instruments". Secondly, in implementing socio-economic and cultural rights, states parties "undertake [to take] such measures to the maximum extent of their available resources". Finally, where needed, the progressive nature of the implementation of economic, social and cultural rights should be undertaken within the framework of international cooperation. ${ }^{67}$ The Limburg Principles clearly state that it is the responsibility of the states to "use all appropriate means, including legislative, administrative, judicial, economic, social and educational measures" in order to fulfil the obligations under the ICESCR. ${ }^{68}$ The Principles state further that legislative measures alone are insufficient ${ }^{69}$ and, as such, appropriate remedies including judicial remedies should be provided in certain circumstances. ${ }^{70}$

In the same vein, the Maastricht Guidelines state that economic, social and cultural rights, like civil and political rights, impose obligations to "respect, protect and fulfil". ${ }^{71}$ Each of these obligations includes elements of obligations of conduct and result, and these occur through acts of omission

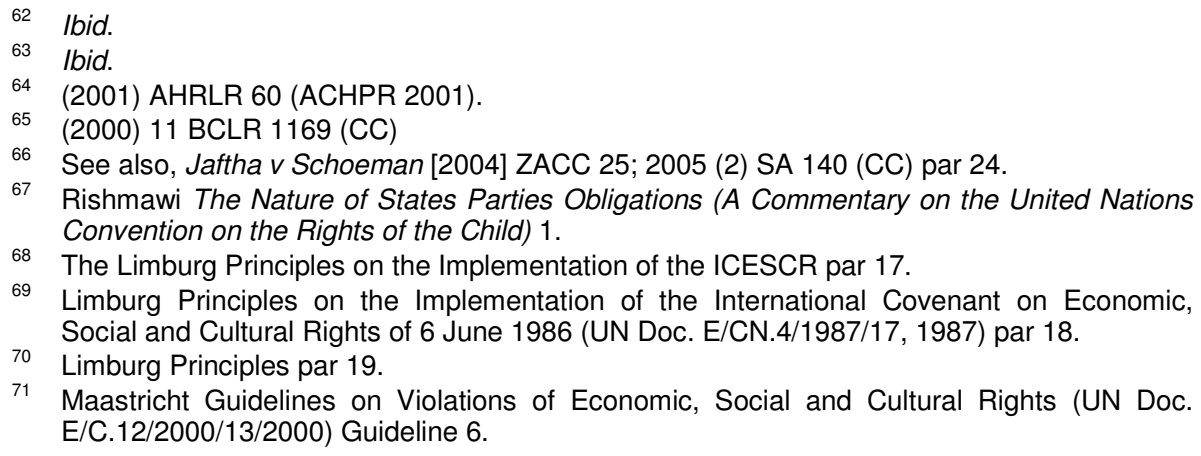

71 Maastricht Guidelines on Violations of Economic, Social and Cultural Rights (UN Doc. E/C.12/2000/13/2000) Guideline 6. 
and acts of commission. ${ }^{72}$ In relation to legislative measures regarding economic, social and cultural rights, the Guidelines state that the violation by acts of commission occurs, for example, by removing or suspending legislation necessary for the continued enjoyment of an economic, social and cultural right that is currently enjoyed; or through the adoption of legislation or policies which are manifestly incompatible with pre-existing legal obligations relating to the rights. ${ }^{73}$ Also, violations through acts of omission occur through the failure to reform or repeal existing legislation. ${ }^{74}$ The three levels of states' obligations will now be examined.

\section{Levels of states' obligations: Obligations to respect, protect and fulfil}

A combined reading of articles 2-5 and articles 13-14 of the ICESCR, as well as articles 4 and 28 of the CRC, illustrates that most of the obligations enshrined in these provisions are of a positive nature. These require a more active policy on the part of states, which can be categorized as obligations to respect, protect and fulfil. ${ }^{75}$ The three levels of obligations on states arising from the right to education as protected in the ICESCR were addressed by the CESCR in its General Comment $13 .{ }^{76}$ The Committee stated: "[t]he right to education, like all human rights, imposes three types or levels of obligations on States parties: the obligations to respect, protect and fulfil. In turn, obligation to fulfil incorporates both an obligation to facilitate and an obligation to provide.,"77

The obligation "to respect" requires states parties to take measures that hinder or prevent third parties from interfering with the enjoyment of the right to education. ${ }^{78}$ This obligation requires states to guarantee the exercise of the right to education in horizontal relations. ${ }^{79}$ In this sense, states must inter alia take measures, for example, to prevent and fight against discrimination in education organized by private educational institutions, and make sure that parents and employers do not stop children (especially girls) from going to school. ${ }^{80}$ This obligation requires a state party to refrain from all measures

72 Maastricht Guidelines, Guideline 7; and see also Rishmawi The Nature of States Parties Obligations (A Commentary on the United Nations Convention on the Rights of the Child) 6.

73 Maastricht Guidelines, Guideline 14(a) and (d).

74 Maastricht Guidelines, Guideline 15(b).

75 See Committee on Economic, Social and Cultural Rights (CESCR) General Comment No 13: the Right to Education (E/C.12/1999/10 of 8 December 1999) par 47; see also the Maastricht Guidelines 6; and Eide "Economic, Social and Cultural Rights as Human Rights" in Eide, Krause and Rosas (eds) Economic, Social and Cultural Rights (2001) 23-24.

76 See generally, Olowu An Integrative Right-Based Approach to Human Development 28-31. and see also Liebenberg Socio-Economic Rights Adjudication under a Transformative Constitution (2010) 82-85.

77 General Comment 13, par 46 (author's own emphasis added).

78 General Comment 13, par 47.

79 Verheyde A Commentary on the United Nations Convention on the Rights of the Child Article 28: The Right to Education (2006) 51.

80 Verheyde A Commentary on the United Nations Convention on the Rights of the Child Article 28: The Right to Education 51. 
that directly or indirectly interfere, impair, hinder or prevent the enjoyment of the right to education for all those within its jurisdiction. ${ }^{81}$ For example, states must refrain from denying or limiting equal access for all individuals and groups to all levels of education, primary or fundamental, secondary or higher, on prohibited grounds. In addition, states are obliged to refrain from acts such as the closure of public or private schools that comply with minimum educational standards; approving corporal punishments in schools; limiting access to means of maintaining education; censoring or withholding education-related information and limiting access to education services as a punitive measure. ${ }^{82}$

The obligation "to protect" the right to education requires states parties to take measures that prevent third parties from interfering with the enjoyment of the right to education. ${ }^{83}$ In terms of this obligation, States are required to take measures, through legislation or by other means, to prevent and prohibit third parties (private groups and individuals) from interfering with the enjoyment of the right to education. ${ }^{84}$ This will require, for example, that the state adopt legislation or other measures to ensure equal access to education provided by third parties by ensuring that private educational institutions do not discriminate in making admissions. Similarly, the state must ensure that third parties, including parents and employers, do not prevent girls, women and other disadvantaged or marginalized groups from having access to education. States also have the obligation to prevent early marriage that interferes with the child's education. Protection also demands that states establish "minimum educational standards" to which all educational institutions, including private institutions, are required to conform. A state must also ensure that teachers and other education professionals meet appropriate standards of education, skill and ethical codes of conduct. ${ }^{85}$

The obligation "to fulfil" on the other hand requires a variety of positive measures from states in order to make the various types of education available and accessible for all and to maintain that level of realization. ${ }^{86}$ In this regard, States are required to adopt appropriate measures, legislative, administrative, budgetary, judicial, promotional and other measures, towards the full realization of the right to education. This obligation involves both an obligation of conduct (to take certain steps) and an obligation of result (to achieve a specific result) such as free and compulsory primary education or progressive introduction of free secondary and higher education. In order to achieve this, a state is obliged, inter alia, to give sufficient recognition to the

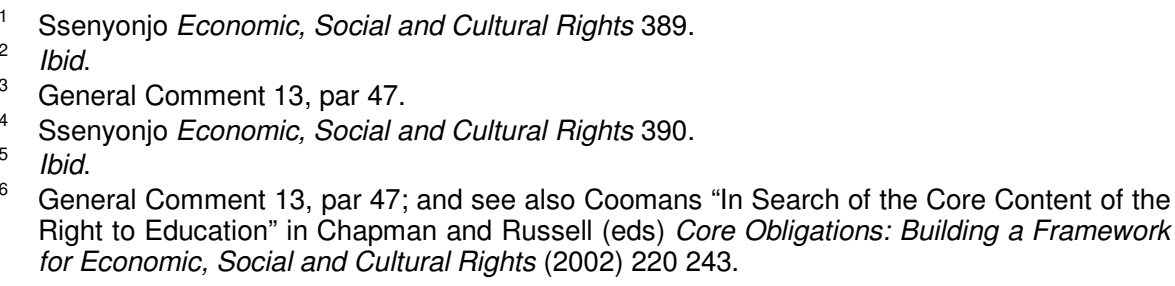


right to education in the national political and legal systems in existence, preferably by way of legislative implementation. ${ }^{87}$

The obligation to fulfil also contains the obligations to facilitate and to provide. $^{88}$ The obligation "to facilitate" requires states to take positive measures that enable and assist individuals and communities to enjoy the right to education. For example, it imposes an obligation on states to reduce the number of school drop-outs and to prohibit child labour that interferes with child education. ${ }^{89} \mathrm{~A}$ state is, in addition, obliged to facilitate the availability of education by taking positive measures to ensure that schools and teachers are available in sufficient numbers. ${ }^{90}$ Further, in terms of this obligation, states have the primary responsibility for the direct provision of education at the levels of primary, secondary and higher education. ${ }^{91}$ States are also obliged to ensure that education meets the requirement of adaptability by designing and providing resources for curricula that reflect the contemporary needs of students in a changing world. States are, furthermore, to fulfil (provide) the requirement of availability of education by actively developing a system of schools, including building classrooms, delivering programmes, providing teaching materials, training teachers and paying them domestically competitive salaries. ${ }^{92}$ Finally, states may fulfil the right to education by assisting, for example, through a system of scholarships for those who cannot afford fees charged for education. ${ }^{93}$

Summarizing the foregoing, the nature and the content of the three levels of education will impose the following obligations on the states: provision of primary/basic education that is free and compulsory; ${ }^{94}$ progressive introduction of free secondary and higher education; ${ }^{95}$ access to public educational institutions and programmes on a non-discriminatory basis; ${ }^{96}$ educational quality that conforms to the internationally recognized objectives; ${ }^{97}$ encouraging regular attendance at schools and ensuring the reduction of drop-out rates; ${ }^{98}$ development of a system of schools at all

Ssenyonjo Economic, Social and Cultural Rights 390.

88 Verheyde A Commentary on the United Nations Convention on the Rights of the Child Article 28: The Right to Education 51; and Ssenyonjo Economic, Social and Cultural Rights 390.

89 Verheyde A Commentary on the United Nations Convention on the Rights of the Child Article 28: The Right to Education 51.

90 See art 12(2) of the Protocol to the African Charter on Human and Peoples' Rights on the Rights of Women in Africa which obliges states to facilitate the realization of the women's rights to education.

91 General Comment 13 par 48.

92 General Comment 13 par 50.

93 In this regard, art 11(3)(e) of the African Charter on the Rights and Welfare of the Child (ACRWC) obliges states to "take special measures in respect of female, gifted and disadvantaged children, to ensure equal access to education for all sections of the community".

94 See art 13(2), ICESCR; art 28(1), CRC \& art 11(3)(a), ACRWC.

95 Art 13(2)(b) \& (c), ICESCR; art 28(1)(b), CRC \& art 11(3)(b), ACRWC

96 See art 26(1), UDHR; art 13(1), ICESCR; art 29(1), CRC; art 3 UNESCO Convention; art 5, CERD \& art 10, CEDAW.

97 See art 26(2), UDHR; art 13(1), ICESCR; art 29, CRC and art 12(2) ACRWC).

98 See art 28(1)(e) of the CRC. 
levels, establishment of an adequate fellowship system and continuously improving material conditions of teaching staff; 99 and guarantee of parental choice in the education of their children without interference from the state or third parties, subject to conformity with "minimum educational standards". ${ }^{100}$

In terms of article 2(1) of the ICESCR quoted above, states may fulfil the obligations imposed on them "progressively" and "to the maximum extent of their available resources". ${ }^{101}$ It should be noted that the inclusion of "progressive realisation" in the provision is in recognition of the fact that full realization of these rights may generally not be achieved in a short period of time because of a lack of financial and other resources. ${ }^{102}$

Notwithstanding the notion of progressive realization, it is submitted that this provision does not diminish the clear obligation on the states parties to ultimately achieve full realization of the right to education. States parties are obliged to take steps within a reasonably short period of time after adopting these Covenants in order to move towards the goal of full realization as expeditiously and effectively as possible. ${ }^{103}$ Such steps must be deliberate, concrete and targeted towards the full realization of the right to education. ${ }^{104}$ The budgetary allocation for education is one of the indicators to determine the commitment of the state parties to education. Thus, regressive measures such as a decrease or reduction in the education budget will be incompatible with the interpretation of the word "progressively". ${ }^{105}$ Such measures will also constitute a violation of the ICESCR, ${ }^{106}$ and are therefore impermissible. ${ }^{107}$

In its reporting guidelines, the CRC Committee requests states to provide information on the proportion of the overall budget devoted to children and allocated to the various levels of education. ${ }^{108}$ In its concluding observations flowing from state parties' reports, the Committee expressed concern about insufficient resource allocation to education and, therefore, encouraged state

99 See art 13(2)(e) of the ICESCR.

100 See art 13(3) and (4), ICESCR and CESCR General Comment 13, par 57.

101 See also, arts 4 and 28(1) of the CRC; and see also Olowu An Integrative Right-Based Approach to Human Development 27.

102 See CESCR Committee, General Comment No. 3 on the Nature of States Parties Obligations 1990 (UN Doc. HRI/GEN/1/Rev.5, 2001) par 9; and CRC Committee, General Comment No. 5: General Measures of Implementation of the Convention on the Rights of the Child (UN Doc. CRC/GC/2003/5, 2003) par 7.

103 General Comment 3, par 2 and 9; the Limburg Principles par 21; and CESCR Committee, General Comment 13 par 44

104 General Comment 13 par 43; General Comment 3 par 2 and 9.

105 Hodgkin and Newell Implementation Handbook for the Convention on the Rights of the Child (2002) 411; and see also Verheyde A Commentary on the United Nations Convention on the Rights of the Child - Article 28: The Right to Education 52-53.

106 The Maastricht Guidelines 14(g) states: "violations of economic, social and cultural rights can occur through the direct action of States or other entities insufficiently regulated by States. Examples of such violations include: $(\mathrm{g})$ The reduction or diversion of specific public expenditure, when such reduction or diversion results in the non-enjoyment of such rights and is not accompanied by adequate measures to ensure minimum subsistence rights for everyone."

107 General Comment 3 par 9.

108 CRC Committee, General Guidelines Regarding the Form and Contents of the Periodic Reports (UN Doc. CRC/C/58, 1996) par 106. 
parties to raise budgetary allocations for education services. ${ }^{109}$ However, the Committee refrained from stating the precise proportion of the national budget which should be allocated to education, thereby allowing a "margin of discretion" to the states as to the means to accomplish these obligations. ${ }^{110}$ The precise content of these obligations is, therefore, likely to vary from one state to another. This is also likely to vary over time in relation to the same state. ${ }^{111}$

Thus, the margin of discretion which exists raises the difficult question as to the exact occurrences which would result in the failure of a state to use the maximum available resources amounting to a breach of an international obligation. ${ }^{112}$ The concept of "the minimum core content" has been developed to address this problem by determining a basic floor of rights realization below which a state may be considered to be acting in contravention of internationally recognized socio-economic rights. The next section is devoted to examining this concept as it applies to the right to education.

\section{The "minimum core" concept as a determinant of violation}

When a state ratifies a covenant, the ultimate result is the full implementation of the various components of each of the rights recognized under the covenant. ${ }^{113}$ In order to fulfil this obligation, a state should first tackle certain "elements of the right that are the most essential or fundamental" in circumstances where resources are highly scarce. ${ }^{114}$ Such elements constitute the "minimum core content" of a right, which translates into "minimum core entitlements" individual or groups, and "minimum core obligations" for states. ${ }^{115}$ The minimum core content is that part of a right,

109 See eg, CRC Committee, Concluding Observations: Nigeria (UN Doc. CRC/C/50, 1996) par 63; CRC Committee, Concluding Observations: Lebanon (UN Doc. CRC/C/54, 1996) par 36; CRC Committee, Concluding Observations: Zimbabwe (UN Doc. CRC/C/54, 1996) par 85 and 98; CRC Committee, Concluding Observations: Portugal (UN Doc. CRC/C/46, 1995) par 149; CRC Committee, Concluding Observations: Yemen (UN Doc. CRC/C/50, 1996) par 45 and 51; CRC Committee, Concluding Observations: Burundi (UN Doc. CRC/C/100, 2000) par 104; CRC Committee, Concluding Observations: Nigeria (UN Doc. CRC/C/118, 2002) par 75; and CRC Committee, Concluding Observations: Pakistan (UN Doc. CRC/C/133, 2004) par 187.

110 Verheyde A Commentary on the United Nations Convention on the Rights of the Child 54; and see also Ssenyonjo Economic, Social and Cultural Rights 54.

111 See Hunt State Obligations, Indicators, Benchmarks and the Right to Education (UN Doc. E/C.12/1998/11, 1998) par 6.

112 See Verheyde A Commentary on the United Nations Convention on the Rights of the Child - Article 28: The Right to Education 53-54.

${ }^{113}$ CRC Committee, General Comment No. 5: General Measures of Implementation of the Convention on the Rights of the Child (UN Doc. CRC/GC/2003/5, 2003) par 2; and see also Ssenyonjo Economic, Social and Cultural Rights 65.

114 Chapman and Russell "Introduction" in Chapman and Russell (eds) Core Obligations: Building a Framework for Economic, Social and Cultural Rights (2002) 1-19 9.

115 Russell "Minimum State Obligations: International Dimensions" in Brand and Russell (eds) Exploring the Core Content of Socio-Economic Rights: South African and International 
which must be respected and protected at all times, whatever the state's level of development and available resources. ${ }^{116}$ It is an absolute international minimum, and constitutes a basic level of subsistence necessary for a life of dignity. Alston has described this as "an absolute minimum entitlement, in [the] absence of which a state party is considered to be in violation of its obligations." ${ }^{117}$

The notion of "minimum core content" refers to the essence and core substance of a right which may not be violated by any state in respect of a particular right. ${ }^{118}$ It ensures the satisfaction of, at the very least, minimum essential levels of rights realization. ${ }^{119}$ It is the essential element or elements without which a right loses its substantive significance as a human right and in the absence of which a state party should be considered to be in violation of its international obligations. ${ }^{120}$ It is regarded as a "floor" below which this condition should not be permitted to fall. ${ }^{121}$ Noting this, the CESCR submitted:

"[T]he Committee is of the view that a minimum core obligation to ensure the satisfaction of, at the very least, the minimum essential levels of each of the rights is incumbent upon every State Party. Thus, for example, a State Party in which any significant number of individuals is deprived of basic foodstuffs, of essential primary health care, of basic shelter and housing, or of the most basic forms of education is, prima facie, failing to discharge its obligations under the Covenant. If the Covenant were to be read in such a way as not to establish such a minimum core obligation, it would be largely deprived of its raison dêtre ..."

It should be pointed out that the purpose of the minimum state obligations approach is not to give states an escape route for avoiding its responsibilities under the ICESCR. ${ }^{123}$ Rather, it is a way to take into account the fact that many economic, social and cultural rights require resources that are simply not available in developing countries. Today, there is positive appreciation of the concept of "progressive realisation" as implying the

Perspectives (2002) 11-21; and see also Olowu An Integrative Right-Based Approach to Human Development 31.

116 Ssenyonjo Economic, Social and Cultural Rights 66.

117 Alston "Out of the Abyss: The Challenges Confronting the New UN Committee on Economic, Social and Cultural Rights" 19879 Human Rights Quarterly 332353.

118 Verheyde A Commentary on the United Nations Convention on the Rights of the Child Article 28: The Right to Education 54; CESCR CESCR Committee, General Comment No. 3 on the Nature of States Parties Obligations 1990 (UN Doc. HRI/GEN/1/Rev.5, 2001) par 10; Arambulo Strengthening the Supervision of the International Covenant on Economic, Social and Cultural Rights, Theoretical and Procedural Aspects (1999) 130-136; and Coomans "In Search of the Core Content of the Right to Education" in Core Obligations: Building a Framework for Economic, Social and Cultural Rights 220 225-246.

119 Maastricht Guidelines 9.

120 Russell "Minimum State Obligations: International Dimensions" in Exploring the Core Content of Socio-Economic Rights: South African and International Perspectives 14 and 15.

121 Roithmayr "Access, Adequacy and Equality: The Constitutionality of School Fee Financing in Public Education" 2003 19(3) SAJHR 382 402; and Russell "Minimum State Obligations: International Dimensions" in Exploring the Core Content of Socio-Economic Rights: South African and International Perspectives 15.

122 CESCR General Comment 3 par 10.

123 Olowu An Integrative Right-Based Approach to Human Development 33. 
avoidance of retrogressive measures that reduce either the number of beneficiaries who have access to the rights or the substance of the benefits. ${ }^{124}$ Even in highly austere circumstances, a state has an irreducible obligation that it is assumed to be able to meet, and it shifts the burden of proof to the state if it claims that it cannot meet these most minimal obligations. ${ }^{125}$ Therefore, even where the available resources are demonstrably inadequate, the obligation remains on a state party to strive to ensure the widest possible enjoyment of the relevant rights under the prevailing circumstances. ${ }^{126}$ In order for a state party to be able to attribute its failure to meet at least its minimum core obligations to a lack of available resources, it must discharge the onus of demonstrating that every effort has been made to use all resources that are at its disposition in an effort to satisfy, as a matter of priority, those very basic minimum obligations. ${ }^{127}$ It is also expected of such a state to seek international assistance and cooperation in this respect. ${ }^{128}$

It should be noted, however, that the fact that the minimum core content of a right must be realised immediately does not suggest that the remainder of such a right is unimportant, thereby somehow justifying state inertia, neglect or denial. Rather, the minimum core should only be seen as a "springboard" for further action by states. ${ }^{129}$ After a state has substantially met its minimum core obligations, it is still obliged to progressively realize the remainder of a right. ${ }^{130}$ While there remains a gap between the actual achievement of minimum core obligations and the objective "universal" standard of minimum essentials for each right in the ICESCR, it is obvious that the central concern of the CESCR is to ensure that state parties demonstrate their unwavering commitment to the protection of vulnerable members of society. ${ }^{131}$

In order to implement the content of the right to education, states are specifically obliged to make education available, accessible, acceptable and adaptable. This is referred to as the 4-A typology. ${ }^{132}$ The 4-A typology of

124 Ibid.

125 Russell "Minimum State Obligations: International Dimension" in Exploring the Core Content of Socio-Economic Rights 16.

126 CESCR General Comment 3 par 11; see also, Russell "Minimum State Obligations: International Dimension" in Exploring the Core Content of Socio-Economic Rights 16.

127 CESCR General Comment 3 par 10 (author's own emphasis added).

128 It should be noted that the term "resources" in terms of ICESCR refers to both the resources existing within a state and those available from the international community through international cooperation and assistance. See General Comment 3 par 13; Limburg Principles 26 and art 2(1), ICESCR. A state claiming that it does not have enough resources to fulfil these core obligations has the burden to prove that this is due to reasons beyond its control and that it has unsuccessfully sought to obtain international support. See Eide "Economic, Social and Cultural Rights as Human Rights" in Economic, Social and Cultural Rights 23-24.

129 Van Bueren "The Minimum Core Obligations of States" in Chapman and Russell (eds) Core Obligations: Building a Framework for Economic, Social and Cultural Rights (2002) 160.

130 Ssenyonjo Economic, Social and Cultural Rights 67.

131 See Olowu An Integrative Right-Based Approach to Human Development 32.

132 See Tomasevski "The Special Rapporteur on the Right to Education: Preliminary Report" (UN Doc E/CN.4/1999/49 of 13 January 1999) par 50; and Ssenyonjo Economic, Social and 
education denotes access to education on a non-discriminatory basis (accessibility); the right to enjoy free and compulsory primary education (availability); the right to quality education (adaptability); and the right to free choice of education (acceptability). ${ }^{133}$ The following elements have, as a result, been identified as constituting the "core content" or the "minimum claims" of the right to education: the right to enjoy free and compulsory primary education; the right to special facilities for persons with an educational deficit or who would otherwise have no access to education at all, such as girls, children in rural areas, working children, street children, and so on; and finally, the right to quality education at each educational level. ${ }^{134}$

The concept of the minimum core content with regard to the right to education has also been elaborated upon by the CESCR. ${ }^{135}$ The Committee states that in the context of article 13 of the ICESCR, this core includes:

"[A]n obligation: to ensure the right of access to public educational institutions and programmes on a non-discriminatory basis; to ensure that education conforms to the objectives set out in article 13(1); to provide primary education for all in accordance with article 13(2)(a); to adopt and implement a national educational strategy which includes provision for secondary, higher and fundamental education; and to ensure free choice of education without interference from the State or third parties, subject to conformity with 'minimum educational standards' (art13 (3) and (4)."

The foregoing forms the basis or foundation on which the implementation of the right to education in South Africa and Nigeria will be assessed in this article. In doing this, the right to primary, secondary and higher levels of education as guaranteed in both countries will be reviewed.

As discussed earlier, implementation is a process whereby states parties take action to ensure the realization of all rights contained in a particular convention in their respective jurisdictions. While it is the state that undertakes obligations in terms of a particular instrument, the task of implementation should engage and involve all sectors of societies. ${ }^{137}$ State parties are obliged to take all appropriate legislative, administrative, and

Cultural Rights 386. It has been argued that there exists a clear relationship of minimum core concept with elements of the "4-A" typology in respect of the right to education. See Coomans "Content and Scope of the Right to Education as a Human Right and Obstacles to Its Realisation" in Human Rights in Education, Science and Culture 197.

133 Coomans "Content and Scope of the Right to Education as a Human Right and Obstacles to Its Realisation" in Human Rights in Education, Science and Culture 197-203.

134 See Coomans "In Search of the Core Content of the Right to Education" in Core Obligations: Building a Framework for Economic, Social and Cultural Rights 217-246, 220 and 225-231; Van Bueren "The Minimum Core Obligations of States under Article 10(3) of the International Covenant on Economic, Social and Cultural Rights" in Core Obligations: Building a Framework for Economic, Social and Cultural Rights 147-160 and 150-153; and Verheyde A Commentary on the United Nations Convention on the Rights of the Child Article 28: The Right to Education 54-56.

135 At its $21^{\text {st }}$ Session, 15 November to 3 December 1999.

136 See CESCR General Comment 13 par 57.

137 Verheyde and Goedertier A Commentary on the United Nations Convention on the Rights of the Child 1 par 1; and CRC General Comment 5 par 2. 
other measures for the implementation of the rights guaranteed. ${ }^{138}$ While article 2(1) of the ICESCR mentions the adoption of legislative measures as part of "all appropriate" means, the CESCR asserts that the phrase "by all appropriate means" must be given its full and natural meaning. ${ }^{139}$ The measures, other than legislation, considered by the CESCR to be appropriate for implementing the ICESCR include the provision of judicial remedies; administrative, financial, educational; and social measures. ${ }^{140}$ The next section will now examine the implementation measures put in place to ensure the realization of the right to education.

\section{MEASURES OF IMPLEMENTING THE RIGHT TO EDUCATION}

Apart from enumerating the nature of the states' obligations, article 2(1) of the ICESCR also states the measures or steps required for implementing the rights guaranteed under the Covenant. In terms of article 2(1) of the ICESCR, each state party undertakes to take steps, individually and through international assistance and co-operation, especially, economic and technical, to the maximum of its available resources, with a view to achieving progressively the full realization of the rights recognized in the Covenant. In achieving this, states parties are required to take all appropriate means, including particularly the adoption of legislative measures. ${ }^{141}$ In the same vein, article 4 of the CRC provides that "States Parties shall undertake all appropriate legislative, administrative, and other measures for the implementation of the rights recognised in the present Convention ....142 These provisions are comparable with the provision of article 2(2) of the ICCPR which also recommends legislative and other measures. ${ }^{143}$

${ }^{138}$ See art 4 of the CRC. In addition, the Committee on the Rights of the Child has identified a wide range of measures that are needed for effective implementation, including the development of special structures and monitoring, training and other activities in government, parliament and the judiciary at all levels. See CRC General Comment 5 par 2.

139 CESCR General Comment 3 par 3 and 4.

140 CESCR General Comment 3 par 5 and 7.

141 Authors' own emphasis added. The term "progressive realisation" has been interpreted to mean the dismantling of a range of legal, administrative, operational and financial obstacles which impede access to the rights, and the expansion over time of such access, to a larger number and broader range of people. See Government of the RSA v Grootboom 2001 (1) SA 46 (CC); 2000 (11) BCLR 1169 (CC) par 45; and see also Liebenberg Socio-Economic Rights Adjudication under a Transformative Constitution 187.

142 Authors' own emphasis added.

143 Art 2(2) of the ICCPR states: "[w]here not already provided for by existing legislative, or other measures, each State Party to the present Covenant undertakes to take the necessary steps, in accordance with its constitutional processes and with the provisions of the present Covenant, to adopt such laws or other measures as may be necessary to give effect to the rights recognised in the present Covenant." A similar provision is also contained in article 1 of the African Charter on Human and Peoples' Rights which provides: "[t]he Member States of the Organization of African Unity, Parties to the present Charter shall recognise the rights, duties and freedoms enshrined in this Charter and shall undertake to adopt legislative or other measures to give effect to them. See also art 1(1), ACRWC adopted by the OAU in 1990 (OAU Doc. CAB/LEG/24.9/49). 
It should be noted that international human rights are meaningless and worthless if they cannot be implemented. ${ }^{144}$ It has been argued that the implementation of international human rights should primarily be done through action at the national level. In this regard, Verheyde and Goedertier submit that the implementation of the rights enshrined in the UN Conventions is primarily a matter of national legislation, policies and litigation. ${ }^{145}$ It is, therefore, submitted that the efficacy or otherwise of a human-rights treaty can only be assessed on the basis of its domestic effect, that is, its status within a particular legal system. ${ }^{146}$ Implementation at the national level implies, in the first place, the inclusion of the international human-rights provisions in the national legal order, principally through the adoption of national legislation. ${ }^{147}$

However, the texts of both the ICESCR and the CRC show that the implementation of these Conventions cannot be considered solely as a national concern. ${ }^{148}$ For instance, articles 43 to 45 of the CRC provide for an implementation function performed by the CRC Committee at the international level. ${ }^{149}$ Also, the existence of the CRC Committee is based on the belief that absence of an international system of control would probably lead to wholesale failure by states parties to progressively fulfil their obligations under the Convention. It should, in addition, be noted also that the Committee was established to assist governments to strengthen national mechanisms as part of the process of realizing the provisions of the CRC. ${ }^{150}$ In this part only the legislative measures will be examined while nonlegislative measures will be discussed in the second article.

\section{Legislative measures}

The legislature is perhaps the main institution responsible for the national protection of human rights because it represents "the will of the people" as the basis of the authority of government. ${ }^{151}$ As Olowu rightly notes, the place

144 Ramolotja queries the purpose of rights if they cannot be implemented thus: "what is the purpose of listing rights in the Constitution if they are not implementable or if nobody has a duty to implement them? What is the purpose of acknowledging a myriad of rights if there are no mechanisms for their implementation or enforcement?" See Ramolotja "The Role of the Courts in the Implementation of Human Rights: The South African Perspective" 1997 XXXVIII (2) Codicillus 31.

145 See Verheyde and Goedertier A Commentary on the United Nations Convention on the Rights of the Child: Articles 43-45 The UN Committee on the Rights of the Child (2006) 1 par 1.

146 Olowu An Integrative Right-Based Approach to Human Development 73.

147 Verheyde and Goedertier A Commentary on the United Nations Convention on the Rights of the Child: Articles 43-45 The UN Committee on the Rights of the Child $1 \mathrm{fn} 2$.

148 See art 2(1) of the ICESCR.

149 See Verheyde and Goedertier A Commentary on the United Nations Convention on the Rights of the Child: Articles 43-45 The UN Committee on the Rights of the Child 1-2 par 1.

150 Verheyde and Goedertier A Commentary on the United Nations Convention on the Rights of the Child: Articles 43-45 The UN Committee on the Rights of the Child 2 par 1.

151 See art 21 of the UDHR which provides that everyone has the right to take part in the government of his country, directly or through freely chosen representatives and that the will of the people shall be the basis of the authority of government. See also, Marie "National 
of legislation in giving tangible meaning to basic social, economic and political priorities in any nation cannot be over emphasized. ${ }^{152}$ Most international human-rights instruments require state parties to take, undertake and adopt "legislative measures" to guarantee the exercise of the right recognized. ${ }^{153}$ Thus, the organization and guarantee of rights and freedoms are regulated by laws prepared and adopted by an assembly elected by the people. ${ }^{154}$ Even when limitations or restrictions on the exercise of certain rights and liberties are necessary, such limitations or restriction must also be provided for in the national law. ${ }^{155}$ The legislature therefore has a central role to play in the protection and implementation of human rights in any country. The CESCR asserts that legislation is, in many instances, highly desirable and, in some cases, indispensable. ${ }^{156}$ For example, it may be difficult to combat discrimination in education effectively in the absence of a sound legislative foundation for the necessary measures required.

Legislative measures in terms of implementation of human rights will require a comprehensive review of all domestic legislation and related administrative guidance to ensure full compliance with the relevant conventions. ${ }^{157}$ It also requires state parties to ensure that the provisions of the relevant conventions are given legal effect within their domestic legal system. ${ }^{158}$ On the obligation to pass relevant legislation, both South Africa and Nigeria have enacted laws towards realizing the right to education, and the positions in the two countries are examined below.

\section{South African legislative measures}

In South Africa, for example, the post-apartheid South African educational system has witnessed a plethora of wide-ranging reform and transformation policies. The starting point is the Constitution itself. The 1996 South African Constitution is viewed as a role model in Africa in terms of its provisions on socio-economic rights in Africa. Socio-economic rights were specifically included as enforceable and justiciable rights in the South African Constitution. ${ }^{159}$ This is one of the reasons why the South African Constitution

Systems for the Protection of Human Rights" in Symonides (ed) Human Rights: International Protection, Monitoring, Enforcement (2003) 257-280 and 260.

152 Olowu An Integrative Right-Based Approach to Human Development 98.

153 See art 2 of the ICESCR, art 4 of the CRC and art 2 of the ICCPR.

154 See Marie "National Systems for the Protection of Human Rights" in Human Rights: International Protection, Monitoring, Enforcement 260. According to Olivier, the implementation of obligations in terms of international law mainly occurs by way of legislation and policy. See Olivier "The Status of International Children's Rights Instruments in South Africa" in Davel (ed) Introduction to Child Law in South Africa (2000) 200.

155 Marie "National Systems for the Protection of Human Rights" in Human Rights: International Protection, Monitoring, Enforcement 260.

156 CESCR General Comment 3 par 3.

157 See CRC General Comment 5 par 18.

158 CRC General Comment 5 par 19 and 23.

159 South African Constitution's socioeconomic-rights provisions have been celebrated internationally. See Kende Constitutional Rights in Two Worlds 244-245; Mubangizi "The Constitutional Protection of Socio-Economic Rights in Selected African Countries: A 
has been described as "the most admirable constitution in the history of the world." ${ }^{160}$ The South African Constitution guarantees the right to education and, specifically, the right to basic education and further education. ${ }^{161}$ Apart from the South African Constitution, other laws that have been made in this respect include the National Education Policy Act, which was enacted to pave the way for bringing the South African education policy in line with constitutional provisions; the South African Schools Act; and the Higher Education Act, among others.

The South African Schools Act 84 of 1996 (the Schools Act) for instance states the government policies and commitments on education. The purpose and object of the Act is clearly set out in its preamble. The long title of the Act states that it was passed in order "[t]o provide for a uniform system for the organization, governance and funding of schools; to amend and repeal certain laws relating to schools; and to provide for matters connected therewith". To ensure education without discrimination, the Act abolished the previously racially-based education system in the country and provides for a uniform system for the organization, governance, standard and funding of schools. ${ }^{162}$ It also obligates the South African provinces to take all reasonable measures to ensure that physical facilities at public schools are accessible to disabled persons. ${ }^{163}$ The Act provides legal backing to the government policy of compulsory education by providing, inter alia, for compulsory school attendance, exception from such attendance and admission and expulsion from public schools. ${ }^{164}$ These measures are in compliance with international obligations of ensuring compulsory primary education as well as education without discrimination as provided for in the ICESCR.

Addressing the imbalances at historically disadvantaged schools has been a central concern in the various South African education laws. It is observed that while redress has existed as an important policy vision, the mechanisms to implement redress have been extremely limited. ${ }^{165}$ For instance, one of the major criticisms of the Schools Act at the time it was passed was that, while it allowed for the possibility of redress, this was not

Comparative Evaluation" 2006 2(1) African Journal of Legal Studies 1-19 2-3; and Brand "Introduction to Socio-economic Rights in the South African Constitutions" in Brand and Heyns (eds) Socio-Economic Rights in South Africa (2005) 1-56 1.

160 Sunstein Designing Democracy, What Constitutions Do 261; See also, Kende Constitutional Rights in Two Worlds 4. It is observed that the South African Constitution's framers surveyed the world's constitutions for the best ideas. Sarkin explains that the framers relied heavily on Canada and German constitutional developments, as well as international human-rights principles. See Sarkin "The Effect of Constitutional Borrowings on the Drafting of South Africa's Bill of Rights and Interpretation of Human Rights Provisions" 19981 University of Pennsylvania Journal of Constitutional Law 176181.

161 See $\mathrm{s} 29$ of the Constitution.

162 See Bray "The South African Schools Act 84 of 1996" in Davel (ed) Introduction to Child Law in South Africa (2000) 285.

163 See s 12(5) of the South African Schools Act (SASA).

164 See ss 3-11.

165 Motala "Reviewing Education Policy and Practice: Constraints and Responses" in Chisholm, Motala and Vally (eds) South African Education Policy Review 1993-2000 (2003) 497-532 506 . 
made obligatory. Section 3(1) of the Act provides for "the funding of public schools on an equitable basis in order to ensure the proper exercise of the right of learners to education", but this provision appears vague and open to many interpretations. ${ }^{166}$ However, the Act did provide for the Minister to set norms and standards in conjunction with the Financial and Fiscal Commission. Legislating on these norms and standards has been welcomed as part of the overall strategy to achieve redress and equity in South African schools. In addition, the main provisions of the Act deal with new norms and standards in the allocation of funding to public schools, subsidies to independent schools and the provision for school fees exemption based on socio-economic criteria. ${ }^{167}$ The new funding policy has been welcomed given its purpose of addressing the inherent imbalances in the quality of education experienced at historically disadvantaged schools.

As mentioned above, states are obliged to remove every obstacle to access to education. Fees and charges constitute such an obstacle as discrimination. Imposition of school fees arguably constitutes discrimination on economic grounds. The South African Constitution gives everyone the right to a basic education but does not specify that it should be free. ${ }^{168}$ The pertinent issue here is whether the state would be fulfilling its positive duties if it provides exemptions from school fees for those who are unable to pay, as is the practice in South Africa. The Schools Act permits fees to be charged but provides exemptions for those who cannot afford them. This is defended on the grounds that, firstly, parents will take more responsibility for their children's education if there is some obligation on their part to pay fees. It is difficult to discover any concrete evidence for this view. Secondly, it is argued that by charging fees to wealthier parents, the government is able to cross-subsidize poorer learners. ${ }^{169}$ However, given that individual exemptions are costly to administer, a fairer and more efficient approach would have been the use of general taxation, where the poorest, who do not earn enough to be liable for taxation, are exempted. ${ }^{170}$

The exemption policy can be defended neither in terms of grounds of effectiveness nor principle. This is because exemptions in effect discriminate against the poorest in society, despite perhaps appearing as a benefit. In terms of the Schools Act, it is unlawful to exclude learners because of parental inability to pay fees. ${ }^{171}$ Schools are also required to grant full or partial exemptions for learners whose families fall within the prescribed means test. ${ }^{172}$ The state does not, however, provide corresponding subsidy for the resulting absence of fee revenue. ${ }^{173}$ The rational response of any individual school, as Fredman rightly argues, is to attempt to maintain its fee

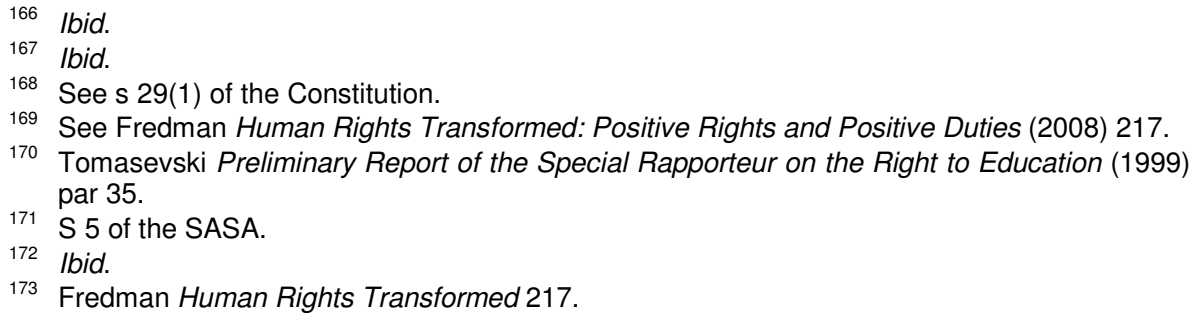

173 Fredman Human Rights Transformed 217. 
income by minimizing its intake of exempt children. ${ }^{174}$ It is observed that schools across the country have taken this path. They have done so in various ways, for example, by concealing from learners their right to claim exemptions; by charging registration fees which poor learners are unable to afford; and even by suing parents in court for fee payment default. ${ }^{175}$

It should be noted that even if a child succeeds in gaining an exemption for the payment of school fees, other costs on items such as transport, school uniforms, and books remain enormous. Moreover, the quality of the school often reflects the fee-paying ability of its pupil body and, as such, schools serving poorer communities inevitably tend to provide a lower quality of education. ${ }^{176}$ Government has taken a more proactive step recently by establishing a framework whereby schools which service very poor communities are declared fee free. Unfortunately, this results in problems of classification arising, since schools in so-called "middle-class" areas frequently serve children from severely deprived neighbouring areas, such as informal settlements. ${ }^{177}$ It is, therefore, submitted that such selective exemptions from fees will inevitably breach both the duty not to obstruct access to education and the duty not to discriminate. ${ }^{178}$ It is further submitted that placing responsibility on parents is a ready pretext for a state abdicating its duties to provide education. While reciprocal responsibilities (as argued to support the imposition of school fees) are part of the concept of active citizenship, this should not permit a transfer of the states' duties onto parents. At most, reciprocal responsibilities on parents should consist of duties outside of the state's reach, such as ensuring that learners attend school regularly, and do their homework.

The system of school fees fundamentally impairs a large number of learners' access to a basic education. ${ }^{179}$ Schools fees and other hidden costs undoubtedly make schooling inaccessible to poor learners. ${ }^{180}$ In this context, and in support of the argument being advanced, it must be noted that the South African Human Rights Commission's Public Hearing on the Right to Basic Education confirmed that transport and uniform costs are often more of a burden on parents than school fees. ${ }^{181}$ This Report suggested a holistic approach in addressing all the barriers to education by recommending the abolition of school fees at primary level; that government should move rapidly to increase the number of fee-free schools available for

180 Khoza Socio-Economic Rights in South Africa 2ed (2007) 430; Jansen "Reflections on Meaningful Access to Education" in South African Child Gauge 2008/2009 (2009) 8.

181 See South African Human Rights Commission Report of the Public Hearing on the Right to Basic Education (2006) par 39-40.
} 
poor learners; and that poor learners who live far from their nearest schools should receive state-transport assistance. ${ }^{182}$

\section{Nigerian Legislation}

In terms of article 2(1) of the ICESCR, Nigeria has also assumed obligations to take legislative measures towards implementing the rights in the Covenant. In this regard, the Constitution of the Federal Republic of Nigeria, 1999 recognizes the right to education, albeit as a non-justiciable right. ${ }^{183}$ However, laws such as the Child's Rights Act, 2003, the Compulsory, Free and Universal Basic Education Act, 2004, (UBE Act), as well as other legislation have been enacted to transform this right into being justiciable. In terms of section 15(1) of the Child's Rights Act, every child has the right to free, compulsory and universal basic education and the government has the duty to provide such free and compulsory education. This is further emphasized by section 2(1) of the UBE Act which obliges every government in Nigeria (federal, state or local governments) to provide free, compulsory and universal basic education for every child until junior secondary school level. ${ }^{184}$ In terms of these laws, it is obligatory for children of school-going age to attend schools. It is also a criminal offence for parents or guardians not to send their children to schools while the government has the duty to provide education.

The compulsory nature of primary education in terms of the UBE Act bestows on the Nigerian government the duty to provide free and compulsory basic education for every child of primary and junior secondary school-going age. ${ }^{185}$ It imposes on a parent or guardian a duty not only to send his or her child to school, but also a duty to ensure that a child continues to attend such a school until after he or she finishes the compulsory terms of schooling. ${ }^{186}$ The Act also provides that "services" provided in public school shall be free of charge. ${ }^{187}$ Services to be provided free of charge include books, instructional materials, classrooms, furniture and launch. ${ }^{188}$ To ensure that these services remain free, the Act makes it a criminal offence for any person to receive fees from parents or guardians of children. Any person who receives or obtains any fee contrary to the provisions of the Act commits an offence and, upon conviction, he or she may be liable to a fine or imprisonment. ${ }^{189}$ Schooling is free in terms of these

182 Par 39-40

183 See s 18 of the 1999 Nigerian Constitution read with s 6(6)(c) of the Constitution.

184 See the decision of the ECOWAS Court in Registered Trustees of the Socio-Economic Rights \& Accountability Project (SERAP) v Federal Republic of Nigeria \& Universal Basic Education Commission (Suit No: ECW/CCJ/App/0808) delivered on 27/10/2009, par 17, where the court held that in terms of Art 17 of the African Charter on Human and Peoples Rights, every Nigerian has the right to education.

185 See UBEC The Compulsory, Free, Universal Basic Education Act, 2004 and other Related Matters (2005) 28.

18622 ; see also, $\mathrm{s} 3$ of the UBE Act.

$187 \mathrm{~S} 3(1)$ of the Act.

$188 \mathrm{~S} 15$ of the Act.

189 S 3(2) of the Act. 
provisions and no one may charge pupils for tuition or any other fees. ${ }^{190}$ While the Act provides for free lunch in public primary school, the reality, however, is that such free-lunch programmes are yet to be implemented throughout the country.

In addition, while the Act provides for free services in the public primary school, hidden costs still abound in Nigerian schools in general. Books are not provided in sufficient quantity and in a few cases where governments provide books and learning materials, they remain inadequate and parents are always forced to complement this through a levy and PTA contributions. Thus, notwithstanding the existence of legislative measures towards ensuring the right to education in Nigeria, access to education in the country is still bedevilled by many factors which include non-availability of schools, the distant location of schools from homes, high cost, inadequacies of physical facilities and inability of the curriculum to meet the basic learning needs of learners. ${ }^{191}$ The challenges of the Nigerian educational system are enormous - a matter which is acknowledged by the government and other role-players in education. ${ }^{192}$ These problems constitute a violation of the Nigerian government's international and/or national obligation to provide education and to make qualitative education accessible to all.

\section{CONCLUSION}

In view of those laws so far analysed, the inevitable conclusion is that there are ample laws in both South Africa and Nigeria on the right to education. The two countries have done considerably well in complying with their international obligations and requirements to take legislative measures towards implementing the right to education. It is submitted, however, that notwithstanding the provisions in both the South African and Nigerian Constitutions and other laws guaranteeing the right to education as considered above, there are still gaps between the laws in the statute-books and the practical realities being experienced by citizens of both countries. While laws and legislation are essential and necessary for implementing the right to education, the experiences from the two countries show that legislation alone is insufficient. Effective implementation of the right to education also requires concerted non-legislative measures backed up with good government policies and political will. The non-legislative measures such as administrative measures, as well as other measures designed to ensure the realization of the right to education are discussed in the follow-up article to this one. The article also identifies some problems hampering the effective implementation of the right to education and makes suggestions on how to ensure an effective realization of the right to education in South Africa and Nigeria.

190 See s 15(1) of the Child's Rights Act, Cap C50, LFN, 2004.

191 See Afonja "The Right of the Child to Education" in Ayua and Okagbue (eds) The Rights of the Child in Nigeria (1996) 66-67; and see also Nwonwu "The Role of Universal Primary Education in Development - Implementation Strategies and Lessons from Past Mistakes" 2008 37(4) Africa Insight 137 138-139.

192 See the Federal Ministry of Education Roadmap to Nigeria Education (2009) 26 and 35. 